\title{
FIJI ISLANDS: FAILURE OF CONSTITUTIONALISM?
}

\author{
Robert Hughes* and Chetan Laksman ${ }^{\dagger}$
}

On 19 May 2000 Fiji experienced its third coup in 15 years when a group lead by George Speight took hostage members of the People's Coalition government. While the coup itself was " a qualified failure", the aftermath left the constitutional situation in Fiji again in crisis.

In this article, the author traces the historical, political, economic and legal factors relevant to the current constitutional situation in Fiji. The author then analyses the predominate constitutional issues facing Fiji. The author suggests that what is urgent is not so much an increased accommodation of indigenous interests in the written constitution, but rather the establishment of some sense of national identity capable of sustaining central government.

\section{INTRODUCTION}

At the present time the constitutional situation in Fiji is in a state of continuing crisis as a result of events which arose in an attempted coup undertaken by a group of persons led by indigenous Fijian (although of mixed race) George Speight on 19 May 2000. A group, including members of the Counter Revolutionary Warfare Unit in the Fiji Military Forces, ${ }^{1}$ led by Speight seized the parliamentary complex on the morning of 19 May 2000 taking hostage members of the People's Coalition government including most of the members of the Cabinet and the Prime Minister, Mahendra Chaudry. Chaudry was the first Indo-Fijian to become Prime Minister of Fiji. The government led by him was the first government to be elected under the 1997 Constitution of the country.

This was the third coup attempt in recent times in Fiji. In May 1987 a full military coup led by then Lieutenant Colonel Sitiveni Rabuku was successful and led to the abrogation of

* Head of School of Law at the University of the South Pacific in Vanuatu. This paper is one of a series of works undertaken as part of the New Zealand Centre for Public Law's Pacific Project. The Centre would like to acknowledge the Victoria Foundation's financial support of this project.

$\dagger \quad$ Research officer at the Institute of Justice and Applied Legal Studies, USP, Suva.

1 The Unit was established by the Rabuku government after the 1987 coup to prevent threats to national security. 
the 1970 Constitution then in force. A second coup took place in October 1987 which led to the removal of then President Ratu Penaia Ganilau from office and the vesting of complete control of the country in Rabuku and the Military.

The attempted coup by the Speight faction was a qualified failure, with Speight and his group ultimately taken captive by the military and several of them charged with offences up to and including treason. However, if judged by other criteria, it was also a success to a certain extent. It threw the country into turmoil, achieved the removal of an elected government, the removal of the first Indo-Fijian Prime Minister of Fiji and an ongoing although questionably legitimate review of the 1997 Constitution. It opened the gates to permit a rush of indigenous sentiment and traditionalist political argument against the alleged liberalisation of the constitution under the 1997 Constitution to re-emerge. It also permitted the Bose Levu Vakaturaga or Great Council of Chiefs to assert itself, through its pretended embodiment of traditional indigenous interests, as a central political authority within the country

A State of Emergency was proclaimed by President Mara on the day of the coup, pursuant to the Public Safety $\mathrm{Act}^{2}$ and section 185 of the Constitution. Emergency Regulations were also promulgated by the President. The events that followed, particularly in Suva, evidenced a progressive breakdown of law and order. On 27 May 2000 President Mara appointed the Hon Ratu Tevita Momoedonu, who was Minister for Labour Industrial Relations and Immigration in the Chaudhry government, to perform the functions of the Prime Minister while the Prime Minister was unable to perform them. On the same day, with the advice of the Acting Prime Minister and pursuant to section 59(2) of the Constitution, the President prorogued Parliament for six months. The Acting Prime Minister then resigned from office, reverting to his former ministerial position. The President did not dismiss the Prime Minister or his Government and did not assume executive control.

Initially the Great Council of Chiefs had firmly supported the actions of President Mara, which sought to uphold the legitimacy of the 1997 Constitution and to act within the framework of legality which it provided. But later that support was withdrawn. On 29 May 2000 after representations of the Commissioner of Police to the President, the military headed by Commodore Voreqe Bainimarama intervened in order, ostensibly, to restore law and order in the country. After a meeting between the President and the Commander, the latter assumed executive authority of the country as "Commander and Head of the Interim Military Government of Fiji." However, it appeared that the President did not resign from office at that time or thereafter but had indicated that should the 1997

2 Public Safety Act (Fiji) Cap 19. 
Constitution be abrogated he would no longer occupy office. He refused to occupy office under a new constitution.

Numerous military decrees and proclamations were immediately issued by the military, one of which was the pretended abrogation of the 1997 Constitution, the abolition of the Supreme Court as the highest constitutional court in the country, the extension of the retirement of the Chief Justice and other measures relating to the maintenance of order. One contentious matter was that certain judges of the High Court of Fiji, including the Chief Justice, Sir Timoci Tuivaga, provided assistance to the military in the drafting of these decrees. Interim Military Government Decree Number 1 purported to abrogate the 1997 Constitution. Decree Number 3 purported to establish an Interim Military Government. Clause 5(2) of this Decree stated that the executive authority of the Republic of Fiji was vested in the Commander as the head of the Military Government. Contrary to the belief by the Commander as to its effect Decree Number 1 did not impose Martial Law on Fiji. Nonetheless this was assumed by the military regime to have been its effect.

Various other Decrees purported both to stabilise the position and bring an end to the hostage crisis. By Interim Civilian Government (Establishment) Decree 2000, ${ }^{3}$ provision was made for an Interim Civilian Government with the Commander as Head of Government. This Decree was proclaimed by the Commander himself. By clause 10 of this Decree the executive authority of the State was then vested in the Head of Government. Ministers in the Interim Government were sworn in by the Commander on the same day. The Immunity Decree 2000, ${ }^{4}$ promulgated by the Interim Government, purported to grant immunity from criminal prosecution and civil liability to George Speight and his supporters.

On the same day the Interim Civilian Government (Transfer of Executive Authority) Decree, ${ }^{5}$ was promulgated, also by the Interim Government. This Decree provided for the appointment of an Interim President and an Interim Vice President. Clause 4 of the Decree provided that the Government "shall have power to make laws for the peace, order and good government of Fiji by means of decrees promulgated by the President on the advice of the Cabinet". By clause 5 the Executive Authority of the State was sought to be vested in the President who was to act only on the advice of the Cabinet. Clause 6 also provided that the Cabinet should consist of a Prime Minister and other Ministers appointed by the President. The decree, signed by the Commander was proclaimed to take effect on 13 July

3 Interim Civilian Government (Establishment) Decree 2000 (4 July 2000) Number 10.

4 Immunity Decree 2000 (9 July 2000) Number 18.

5 Interim Civilian Government (Transfer of Executive Authority) Decree (9 July 2000) Number 19. 
2000. Then on 14 July 2000 the Bose Levu Vakaturaga or Great Council of Chiefs a body which had certain constitutional functions including that of appointment of the President, appointed Ratu Josefa Iloilo, the Vice-President under the 1997 Constitution, as Interim President. It also appointed Ratu Jope Seniloli as Interim Vice President. On the same day the remaining hostages were released and thus the immediate crisis ended.

The Interim President and Vice President were sworn in on 18 July by the Military Commodore. On 28 July 2000 Interim Civilian Government Ministers were sworn in by the Interim President and took office under the Interim Civilian Government (Transfer of Executive Authority) Decree. ${ }^{6}$ This provided the basis for the Interim Civilian Government to occupy the position of government the country. Amongst other things, the Interim Government promulgated the Judicature Decree 2000, ${ }^{7}$ with apparently retrospective effect to 13 July 2000. This Decree provided that the persons holding appointments on 12 July 2000 as Chief Justice, Justice of Appeal, or Judge of the High Court should continue to hold such appointments. It also purported to re-establish, presumably on a new constitutional basis, the High Court of Fiji and the Court of Appeal. Under clause 8(2) of the Decree provision was made for the Chief Justice and the existing Judges of the High Court not to be required to take the oath of allegiance if previously appointed. Clause 15(1) purported to make the Court of Appeal the final Court of Appeal for "the Republic of Fiji". Clause 16(1) purported to repeal the Supreme Court Act 1998 and therefore to remove the highest constitutional Court of the country.

The Interim Civilian Government established a Constitutional Review Committee under the chairmanship of Professor Asesela Ravuvu for the purpose of reviewing the terms of the 1997 Constitution with a view to the better guaranteeing of the rights of indigenous Fijians. This was consistent with the Interim Civilian Government's agenda to secure the rights of indigenous Fijians within the constitutional arrangement in Fiji. This project manifested one of the more curious features of the period of rule by the Interim Civilian Government in Fiji. It was generally supposed by many, including the members of the Interim Civilian Government and the Military, that the 1997 Constitution had been abrogated rather than suspended. The removal of the Supreme Court is perhaps one aspect of this. But at the same time there were frequent occasions when the continuing existence of the Constitution was assumed, by the courts and by those in executive government. Within this confusion the notion of a Committee to review, rather than rewrite, that which was taken to be abrogated seems an absurdity. Yet it reflects a widespread confusion on the constitutional make-up of the country during this period. In this light, the

6 Interim Civilian Government (Transfer of Executive Authority) Decree (9 July 2000) Number 19.

7 Judicature Decree 2000 (17 August 2000) Number 22. 
establishment of such a Committee is no more unusual than the Interim Civilian Government purporting to argue before the Court of Appeal that the Constitution which established the Court in the first place had been completely abrogated.

In Republic of Fiji and Attorney-General of Fiji v Prasad ${ }^{8}$ the Court of Appeal of Fiji Islands on 1 March 2001 made a series of declaratory orders which brought down the regime of Interim Civilian Government headed by Interim Prime Minister Qarase. This judgement varied with some slight, though not insignificant degree, the declarations of Gates J in the first instance but otherwise adopted his conclusions. These were:

- First, the 1997 Constitution remained the supreme law of the Republic of The Fiji Islands and had not been abrogated. The Court held that the President had rightfully proclaimed a State of Emergency given the crisis in the country. This was notwithstanding that the State of Emergency could not be proclaimed "on the advice of the Prime Minister" as provided in section 185 of the Constitution. It also rejected the argument that the 1997 Constitution was or could be completely abrogated by the Commander of the Army pursuant to the doctrine of necessity. In this regard the Court held that the extra-constitutional action (which seemed to include the proclamation of the State of Emergency and the suspension of the Constitution) was a temporary one only. The necessity which was present in these circumstances did not legitimate a permanent abrogation of the legal order. The Court further determined that the Interim Civilian Government could not claim legitimacy pursuant either to that doctrine, or on the grounds of wide popular acceptance. In this regard it approved the statement of Gates J in the court below:

It is obvious therefore that the doctrine of necessity could come to aid Commodore Bainimarama in resolving the hostage crisis, imposing curfews' maintaining road blocks and ensuring law and order on the streets. Once the hostage crisis was resolved and all other law and order matters contained, if not entirely eradicated, the Constitution, previously temporarily on ice or suspended, would re-emerge as the supreme law demanding his support and that of the military to uphold it against any other usurpers. The doctrine could not be used to give sustenance to a new extra-constitutional regime. Nor could it provide a valid basis for abrogating the Constitution and replacing it with a Constitutional Review Committee and an interim civilian government. Necessity did not demand any of that.

$8 \quad$ Republic of Fiji and Attorney-General of Fiji v Prasad (1 March 2001) Court of Appeal Fiji Islands Civil Appeal No ABU0078/2000 <http:// www.vanuatu.usp.ac.fi> (last accessed 13 November 2001). 
In reaching this conclusion the court formulated its own version of efficiency so far as it applies as part of the Common Law of Fiji. ${ }^{9}$ It concluded that there was sufficient evidence of control of the country by the Interim Civilian Government. There was no alternative government or organised regime of resistance to that Government. But the court concluded that the Interim Civilian Government had failed to discharge its burden of establishing that there was any real acquiescence or consent on the part of the wider population to the existence of the Interim Civilian Government. Thus it lacked legitimacy.

- Secondly, the Parliament of the country had not been dissolved. Rather the court held it was merely prorogued on 27 May 2000 for six months.

- Thirdly, the office of the President under the 1997 Constitution became vacant only on the actually resignation of Ratu Sir Kamisese Mara, which took place in fact on 15 December 2000. In accordance with section 88 of the 1997 Constitution, VicePresident Iloilo was permitted to perform the functions of the President until 15 March 2001 unless a President was sooner appointed under section 90 of that Constitution.

The Court of Appeal ruling did not completely restore stability to the country. One of the reasons was that it left open some doubt about which parties would constitute a government and who would be the Prime Minister. The Labour-led coalition (or People's Coalition) seemed itself to be in some perplexity on the issue. The Great Council of Chiefs expressed a token acceptance of the rule of law and of the decision of the Court but its decisions were otherwise presumptuous. It purported to appoint President Ilioilo as President of the country. It left the matter of choice of a Prime Minister to the President but purported to endorse the continuation of the Interim Civilian Government as a caretaker Government pending elections and suggested that the work of the Constitutional Review Committee might continue. President Iloilo chose another route besides direct appointment in order to pay some lip service to the legal procedures required under the 1997 Constitution. He appointed the evanescent Ratu Tevita Momoedonu as Prime Minister solely for purpose of dissolving parliament. When that was done one day later he appointed Laisenia Qarase, the former Interim Prime Minister, as caretaker Prime Minister pending general elections to be held in August 2001.

Before proceeding further we will attempt to outline the historical, economic and social factors which are relevant to the assessment of the constitutional position in the Fiji Islands

9 The court relied particularly on Madzimbamuto v Lardner-Burke [1969] 1 AC 645 (PC), Makenete v Lekhanya [1993] 3 LRC 13 and Mokotso v H M King Moshoeshoe II [1989] LRC (Const) 24. 
both in light of these events and more generally. We will also outline the structure of government and administration provided under the 1997 Constitution.

\section{POLITICAL STATUS AND HISTORY}

According to Fijian legend, Lutunasobasoba led his people across the seas to a new land of Fiji. The islands that now make up Fiji were initially settled from Melanesia. Later there were additional migrations from Melanesia, and invasions of Tongans in the pre-colonial period introduced Polynesian racial and cultural elements, especially in the eastern part of Fiji. Prior to European contact, most of Fiji was divided into small, often warring, social and political units, although strong regional chiefdoms had begun to emerge in the late eighteenth century. The Tongan monarchy had also established hegemony over parts of Fiji for short periods.

In the nineteenth century, the first European settlers came to live among the Fijian people. These were such casual and diffuse classes of arrival as traders, ship wrecked sailors, missionaries, adventurers, plantation owners, beachcombers, and sandalwood traders. The beche de mer and sandalwood traders reached Fiji in 1803 and 1804. The London Missionary Society began its activities in the islands in the 1830s. Cannibalism, which was practised in Fiji at that time, disappeared as the missionaries gradually gained influence.

In the 1850s, the pace of European settlement and commercial activity accelerated, and several American and French warships visited Fiji. The Vunivalu (principal chief) of Bau, Cakobau, who held authority over a considerable portion of Fiji, accepted and was converted to Christianity in 1854 . The rest of the country soon followed, and tribal warfare came to an end. Western clothing was largely adopted. In 1858, a British consul was appointed. Cakobau, in co-operation with certain elements of the European population, formed national governments in 1865 and again in 1871. These governments, however, were unable to withstand a variety of pressures from dissident chiefs, European settlers, and foreign creditors. On 10 October 1874, Cakobau and twelve other Chiefs ceded Fiji to Queen Victoria pursuant a Deed of Cession, making Fiji a British colony.

Initially a Governor ruled the colony, although in 1875 the Governor appointed the Bose Levu Vakaturaga (Great Council of Chiefs) to advise on matters affecting Fijians. During the first half of the twentieth century, Fiji was moved toward the establishment of representative democracy. In 1904, the Legislative Council, which since its inception in 1875 had been entirely composed of Europeans nominated by the Governor, was granted a more representative constitution. This was by way of provision for the election of six Europeans and the nomination of two Fijian members by the Bose Levu Vakaturaga. In 1916 an Indian member of the Legislative Council was nominated by the Governor for the first time, and in 1929 provision was made for the election of three Indian members. The 
Legislative Council was expanded in size until in 1963 it had a membership of 38 a nominated speaker, 19 official members, and 18 unofficial members comprising four elected and two nominated members each from the Fijian, Indian and "general elector" (European, Chinese, and mixed-race) communities. In the 1963 election, women voted for the first time. In 1964, the Executive Council was enlarged and in effect became a Cabinet, with Ministers responsible for specific portfolios. In all these elections, each ethnic community voted from separate rolls.

On 10 October 1970, Fiji gained independence. The Constitution, enacted by the British Privy Council, provided for the Queen to remain Head of State, represented by a Governor-General, who was in most matters to act on the advice of ministers. Ministers were to be appointed by the Governor-General on the advice of the Prime Minister, who in turn was the person considered by the Governor-General as best able to command the support of the House of Representatives. The House consisted of 52 members - 12 Fijian Indian, three general elector members elected from communal rolls, and 10 Fijians, 10 Indians and five general elector members elected from national rolls. The 1970 Constitution also provided for a nominated Senate comprising 22 members - eight nominated by the Bose Levu Vakaturaga, seven by the Prime Minister, six by the leader of the opposition, and one by the Council of Rotuma. From 1970 until 1987 the Alliance Party, largely comprised of indigenous Fijians, was successful in elections, with the exception of the 1977 election in which the National Federation Party won a majority of seats. However, the Governor-General appointed the Alliance leader, Ratu Sir Kamisese Mara as Prime Minister. ${ }^{10}$

On 14 May 1987, after an election won by a Labour-National Federation Party coalition, a successful military coup was led by then Lieutenant Colonel Sitiveni Rabuka of the Fiji Military. The Governor-General, Ratu Sir Penaia Ganilau, declared a State of Emergency, dissolved Parliament, and removed all ministers, replacing them with ministers nominated by himself. On 1 October 1987, the Military again took control of the government by way of a second coup and abolished the 1970 Constitution. On 7 October Fiji was declared a republic, thus severing ties with the British Queen and with the British Commonwealth. The country was from that point on ruled by an interim military government. The former Governor-General agreed to act as President, and in December 1987, the Military government returned control to Ratu Penaia Ganilau. As President, Ratu Ganilau appointed Ratu Mara Prime Minister.

On 25 July 1990, after considerable discussion within the Fijian community of a draft constitution, the Sovereign Democratic Republic of Fiji (Promulgation) Decree was brought

10 Ratu is an honorific generally used by those holding Fijian chiefly titles. 
into effect. The new Constitution confirmed the status of Fiji as a republic, with a President as Head of State and a Prime Minister, Cabinet and Parliament. Indigenous Fijians had a guaranteed majority in the House of Representatives of 70 seats, 37 seats were reserved for Fijians, 27 for Indo-Fijians, five for other races and one for Rotumans. The Senate had a membership of 34 consisting of 24 members appointed on the advice of the Bose Levu Vakaturaga, one appointed from Rotuma and nine appointed by the President from nonFijian communities. The Constitution also stipulated that the Prime Minister be an indigenous Fijian member of the House of Representatives.

The first elections under the 1990 Constitution were held in 1992. They resulted in the appointment of Sitiveni Rabuka as Prime Minister, following victory of the Great Council of Chiefs' sponsored party, Soqosoqo-ni-Vakavulewa-ni-Taukei (SVT). Twenty months later in 1994, another general election was held following the defeat in Parliament of the budget bill. The SVT party again dominated the elections in winning convincingly.

The 1990 Constitution, decreed after the military coups of 1987, was broadly assumed to be a temporary solution to the constitutional problems of the country and provided for its own review within seven years; that is, before 25 July $1997 .{ }^{11}$ The constitutional review process was initiated by Prime Minister Rabuka, who appointed a Cabinet subcommittee, which was expanded to include the opposition members of Parliament. The major parties in Parliament agreed that the review would be completed in time for the 1997 general elections to be held under a revised constitution.

A Constitutional Review Commission was established, comprising of Sir Paul Reeves, ${ }^{12}$ as chairman, Mr Tomasi Vakatora, ${ }^{13}$ as government nominee, and $\mathrm{Mr}$ Brij Lal ${ }^{14}$ as opposition nominee. The terms of reference of the Commission required a comprehensive review of the 1990 Constitution, not only of the electoral system and the composition of parliament, but of issues relating to national unity and the economic and social advancement of all communities in Fiji. The report of the Constitutional Review Commission was submitted to the President on 6 September 1996. It was a very comprehensive report, having some 800 pages and some 694 recommendations. The new constitution received support from the Bose Levu Vakaturaga and all the major parties and stakeholders. The passing of the Constitution also led to Fiji's re-admission as a member of the Commonwealth in October 1997, restoring links with the Crown.

111990 Constitution, s 161.

12 Former Governor General of New Zealand, a Maori.

13 Former Alliance Government Minister, an experienced politician and an indigenous Fijian.

14 An academic (History/Political Studies), a second generation Indo-Fijian. 
On 25 July 1998, the Constitution came into operation and the first elections for the House of Representatives were held in 1999. This produced an outright majority for the Fiji Labour Party, which won 37 of the 71 seats. The leader of the Fiji Labour Party, Mahendra Chaudhry, was appointed as the fourth Prime Minister of Fiji. He was the first member of the Indian community to attain this position.

\section{ECONOMIC SURVEY}

There are approximately 300 islands in the archipelago of Fiji, including many small, uninhabited islets. The two main islands, Viti Levu and Vanua Levu, account for about 87 per cent of the country's total land area of 7,055 square miles. Only two other islands, Taveuni and Kadavu, exceed 100 square miles in area. The whole group of islands (except for Rotuma) lies in a rectangle between 15 and 22 degrees south latitude and 175 degrees west and 175 degrees east longitude.

As of 25 August 1996, the total population was 772,655, with indigenous Fijians outnumbering the ethnic Indians and Chinese, with the Europeans as small minorities. As a result of the 1987 coups, many Indians, and in particular many professional and business people, left the country. Compared to the 1986 census there was a net increase of 57,280 persons during the 1996 census. Fijians had increased by 65,694 persons. Indian numbers, however, registered a decrease of 12,125 persons as a result of high international emigration, and lower rate of national increase. Fiji has a relatively young population with about 53 per cent or 413,100 persons below the age of 25 years.

Before 1800, Fijian communities were self-sufficient, or at most interdependent, within relatively localized trading networks. Since the arrival of the Europeans in the nineteenth century, Fiji has been an export-dominated economy. The beche de mer trade was especially active between 1828 and 1835, and again between 1842 and 1850. Beginning in 1858, trade in coconut oil became important, and German, American, and British commercial interests established themselves in the islands. Cotton, in response to the American Civil War, and sugar were established as export industries in the 1860s. As a result of land purchases and seizures by Europeans, virtually all the most fertile and accessible land had been alienated by the time of cession in 1874. Although more than 80 per cent of all land remained in indigenous Fijian ownership, most of this was economically marginal or worthless.

At the time of cession, the export economy of the new colony was weak. Copra and sugar seemed to have the greatest potential, but both required large numbers of labourers. Because the colonial administration was unwilling to compel Fijians to undertake this work, it approved the shipment of indentured labourers from India. These labourers were free to return to India at their own expense after five years, or after ten years they could elect either to remain in Fiji or to be returned at government expense. Many chose to stay 
on in Fiji after the ten year-period and eventually Indians rose to approximately half the population. The importation of Indian labourers continued until 1916.

The sugar industry itself became increasingly dominated by a single company, Colonial Sugar Refining Company Ltd of Australia. Over the half-century following cession, other agricultural exports declined in importance, and the economy became almost wholly dependent on sugar. Beginning in the 1930s, gold mining and tourism emerged as significant economic sectors. By 1946, the gold industry accounted for more than 20 per cent of Fiji's exports. The economy in the post war years has been based primarily on sugar and tourism. Between 1950 and 1970, exports increased by 6 per cent a year, and the gross domestic product (GDP) per capita increased by 4.5 per cent annually, even while population was growing at 2.5 per cent annually. ${ }^{15}$

The sugar processing industry was nationalized shortly after independence. By 1983, gross national product (GNP) per capita was US\$1,790, compared to an average of US $\$ 1,500$ for middle-income developing countries. ${ }^{16}$ In the 1980 s, however, a series of economic reversals occurred; drought, hurricanes, and a collapse of the world sugar market combined to reduce average living standards. In the immediate aftermath of the 1987 coups, tourism fell off very sharply, and foreign investment declined. Moreover, an unknown but substantial number of business and professional men and women, mostly Indians, left Fiji after the coups. Some recovery was achieved in the sugar and tourism industry and the development of the timber industry provided economic growth from 1989 to 1990.

In 1998 real economic growth was estimated to have declined by 2.5 per cent. This followed a decline of 1.7 per cent in economic growth recorded in 1997. Most of the slowdown in 1998 was observed in the agricultural sector mainly because of the adverse weather condition the country faced during the year. The negative effect of the drought faced by the country in 1997 followed on to affect agricultural output in 1998. Fiji's overseas trade during 1998 showed total exports as F\$938.70 million and imports as F\$1501.50 million, as compared to 1997, total exports showed an increase of F\$85.70 million or 10 per cent while total imports showed an increase of $\mathrm{F} \$ 109$ million or 7.8 per cent. ${ }^{17}$

Following the toppling of the government in May 2000, the Reserve Bank of Fiji ${ }^{18}$ predicted that the economy would contract by about 8 per cent instead of the 13-15 per

15 B Knapman Fiji's Economic History 1874-1939: Studies of Capitalist Colonial Development (Pacific Research Monograph No 15, Australian National University, Canberra, 1978) 1.

16 Pacific Economic Bulletin (National Centre for Development Studies, Canberra, July 1986) 1.

17 Fiji Today (Ministry of Information, Suva, Fiji, 2000).

18 Islands Business (November/December 2000) 36. 
cent growth earlier forecast for 2000. Foreign reserves in November were standing at over \$F800 million. Sugar output for 2000 had been forecast at about 430,000 tonnes. Following the events of 19 May 2000 the economy is expected to follow the post 1987 coups level and the economy is expected to face a downturn for the long term.

\section{CULTURAL FACTORS}

Fiji was initially settled about three and half thousand years ago by the original inhabitants who are now called "Lapita people" after a distinctive type of pottery they produced, remnants of which have been found in practically all islands of Pacific east of New Guinea, though not in eastern Polynesia. Linguistic evidence suggests that they came from northern or central Vanuatu, or possibly the eastern Solomons. The northern island group known as Rotuma was settled by people of Polynesian descent, probably from Vanua Levu, some centuries later than this although the time is somewhat unclear.

Fiji appears to have undergone at least two periods of subtle culture change in prehistoric times. This may have been due to the arrival of fresh waves of immigrants from the west. Prehistorians have noted that a massive twelfth century volcanic eruption in southern Vanuatu coincided with the disappearance there of certain pottery style and its sudden emergence in Fiji. This, and other evidence such as language and kava use, supports the claim that the indigenous Fijians settled from Vanuatu and possibly the northern region of the archipelago.

Before European contact, Fijian social organisation was centered on the family, with several interrelated families forming a village. Families in a village typically traced their ancestry back through the male line to a principal male ancestor. Land was typically held communally, although individuals and families often had inheritable rights to particular plots for houses and gardens, and land tenure patterns differed from one area to another.

Cultural values included mutual aid, exercised by all members of the community, and the sharing of material goods within the community. When newcomers were admitted to a village, they were often required to pay tribute to the village chief, as the representative of the community. A distinction was often made between taukei, the original landowners, and vulagi, or "guests" who came from elsewhere and settled on the land with the original owners' permission. However, these cultural and political patterns were not static. People often moved to new land, formed new alliances, and developed new leadership and ceremonial ties in response to demographic or economic changes.

Two major changes appeared during the nineteenth century. First, Fijians became Christians, in the wake of substantial missionary activity by the London Missionary Society and others. In 1854, Cakobau, one of the most important chiefs, accepted a Wesleyan mission, marking the ascendancy of Christianity over the island of Viti Levu. Second, the foreign consuls and, after 1870, the British colonial government, established a 
system of indirect rule that in effect substantially increased the power of those persons recognised by the Europeans as chiefs.

In the post independence period, these cultural elements have persisted within the Fijian community. The village is still central to Fijian life, although an increasing number of young people have moved to towns in search of employment. Christianity is still considerably important. Virtually all Fijians are active church adherents. The major denomination is Methodist.

The other major cultural element in Fiji is the Indian community. Most of them are descendants of labourers brought to the country from India to work in the sugar plantations about 100 years ago under the indentured labour system. Although they were offered passages back to India after their term, most preferred to stay and regarded Fiji as their home. Through the years they have continued to work the land, becoming prominent in agriculture and also commerce. Most of the Indian immigrants have generally retained their religious ties and caste distinctions have disappeared.

A multi-racial, multi-cultural nation, Fiji is represented by all major religions in the world. Fiji is home to many races - Indians, Part Europeans, Chinese and other Pacific Islanders, with their own culture and identity. There has been some intermarriage between different races but this has been minimal. However, people of all races living in rural areas have adapted well, some even speaking the local dialect and mixing with each other. As a country, Fiji is rurally based with about 60 per cent of the population living in rural areas.

\section{THE MAIN INSTITUTIONS OF GOVERNMENT}

The 1997 Constitution of Fiji Islands sets up a structure of government and an institutional arrangement which is an adaptation of the British responsible government model. The Constitution is expressed to be the supreme law of the country. It provides for a separation of powers between the legislature, the courts and the executive headed by the President. It entrenches notions such as the rule of law, fundamental human rights, affirmative action, equal citizenship and various other principles which are entirely familiar in the context of modern liberal constitutionalist doctrine.

\section{A The Parliament}

The legislative power of the Republic of Fiji Islands is assigned to a Parliament which is constituted by the President, a House of Representatives and an upper house called the Senate. This reflects the orthodox British conception of the Crown as the Monarch in Parliament.

The House of Representatives comprises 71 members who are elected in the manner described below. Unless sooner dissolved, it continues for five years from the date of its 
first meeting after a general election of members of the House (section 59). The Senate consists of 32 members. Of these 14 are appointed by the President on the advice of the Bose Levu Vakaturaga; nine are appointed by the President on the advice of the Prime Minister; eight are appointed by the President on the advice of the Leader of the Opposition; and one is appointed by the President on the advice of the Council of Rotuma. The Senate has limited functions of review of legislation under the 1997 Constitution. It can neither initiate legislation nor reject it, although there are some mechanisms for deferral.

Proceedings in both Houses of Parliament are to be conducted English which is the official language of the Parliament, but a member of either House may address the person presiding in Fijian or Hindustani (section 74). The Houses of Parliament can prescribe their own powers, privileges and immunities. Provision is made by section 74(3) for the appointment by the House of Representatives of not less than five sector standing committees with the function of scrutinising government administration and examining Bills and subordinate legislation, and such other functions as are specified from time to time. Ministers are not eligible for election to these standing committees.

The 1997 Constitution makes more provision that is usual for a written constitution for Cabinet and responsible government. The impression which this excess of detail creates is that there was some urgent need to go into it, possibly thereby sacrificing the flexibility usually achieved by leaving these things to convention. By section 96(1) it is stipulated that the President, in the exercise of his or her powers and executive authority, acts only on the advice of the Cabinet or a Minister or of some other body or authority prescribed by the Constitution for a particular purpose as the body or authority on whose advice the President acts in that case. But there are some instances where the President is entitled to act on his or her own judgment. These are discussed below. Section 97 states that governments must have the confidence of the House of Representatives.

The President appoints the Prime Minister acting on his or her own judgment. The Prime Minister must be a member of the House of Representatives and a person who, in the President's opinion, can form a government that has the confidence of the House of Representatives (section 98). Other Ministers are appointed and dismissed on the advice of the Prime Minister. A Minister must be a member of the House of Representatives or the Senate (section 98(2)).

In the Constitution there is provision for a multi-party Cabinet, which was supposed to provide some acknowledgement of the multi-ethnic composition of the Republic. Section 99(3) provides that the Prime Minister must establish a multi-party Cabinet as provided for in that section comprising such number of Ministers as the Prime Minister determines. The composition of the Cabinet should, as far as possible, fairly represent the parties 
represented in the House of Representatives. In establishing this Cabinet, the Prime Minister is obliged to invite all parties whose membership in the House of Representatives comprises at least 10 per cent of the total membership of the House, to be represented in the cabinet in proportion to their numbers in the House.

The President of the Republic is specifically denied any power to reject any bill passed by the Parliament (section 46(2)). By section 47, all bills must originate in the House of Representatives and following passage of the bill there it is transmitted to the Senate. The Senate's only power is to pass the bill with or without amendment or to reject it.

In the case of amendment by the Senate, the House of Representatives may agree to the amendment, reject it or agree to it in an amended form. Where the amendment is rejected by the House of Representatives, the bill must be returned to the Senate in the form in which it has again been passed by the House of Representatives. Where the bill has been passed by the House of Representatives in two successive sessions, followed by an interval of at least 6 months on each occasion, and on each occasion the Senate rejects it or passes it with an amendment to which the House of Representatives does not agree, then the Bill may be presented to the President for assent. However this does not apply to Bills dealing with group rights as referred to in section 185 .

The Senate is denied by section 49 any power to amend Bills imposing taxation or appropriating revenue or moneys. The Senate is also prohibited from attempting by amendment to increase any proposed charge or burden on the people. Where the Speaker of the House certifies that a Bill passed by the House is an appropriation Bill, the Senate must pass it without amendment by the end of the sitting day after the day on which it was sent to the Senate. Where it does not the Bill must, unless the House of Representatives otherwise resolves, be presented to the President for assent. Similar provision exists with respect to money Bills (sections 49(3) and (4)).

\section{B The Courts}

The court system in Fiji is primarily a two-tiered structure divided between superior courts of record and magistrates courts. The High Court of Fiji is the main superior court with original jurisdiction and some appellate. Above it sits the Court of Appeal and the Supreme Court. The jurisdiction of the respective courts is as follows: ${ }^{19}$

19 See J Corrin-Care, T Newton and D Paterson Introduction to South Pacific Law (Cavendish Publishing Ltd, London, 1999) 284-289. 


\section{The Supreme Court}

The Supreme Court sits at the apex of the court system in Fiji. The court is the final appellate court in both criminal and civil matters. It has exclusive jurisdiction to hear and determine appeals from all final judgments of the Court of Appeal but only with leave of the Court of Appeal or special leave of the Supreme Court itself.

Appeals as of right lie to the Supreme Court from final decisions involving any constitutional question; and from final decisions in proceedings involving $F \$ 20,000$ or more. However, the President may on the advice of the Cabinet, refer questions as to the effect of the Constitution to the Supreme Court for an opinion.

\section{The Court of Appeal}

Below the Supreme Court there lies the Court of Appeal. It has jurisdiction with respect to appeals from judgments of the High Court. Appeals lie as of right with respect to final judgements in civil matters in three areas. These are (a) in matters arising under the Constitution or involving its interpretation; (b) from final decisions involving interpretation of the Judicature Act 1988; and (c) from final decisions given in the exercise of original jurisdiction under the fundamental rights provisions of the Constitution, including deprivation of property. Other applications require leave.

In respect of criminal matters a right of appeal to the Court of Appeal is accorded to a person who has been convicted on trial before the High Court as follows: (a) against conviction on any ground involving only a question of law; (b) with leave of the Court of Appeal; and (c) with leave of the Court of Appeal against sentence unless it is one that is fixed by law. Any party who seeks to pursue a further appeal from a criminal appeal disposed of by the High Court is permitted to do only where the High Court did not affirm a verdict of acquittal by a magistrates' court and, furthermore, only if the ground of appeal involves a question of law (not involving severity of sentence).

\section{The High Court}

The High Court is the primary superior court with original jurisdiction in the Fiji court system. It is conceded unlimited jurisdiction to hear and determine civil proceedings. Furthermore it has appellate jurisdiction in relation to decisions of magistrates' courts.

Appeals to the High Court in criminal matters can be made in relation to matters of fact, as well as law. Any question of law can be referred by a magistrate to the High Court. for determination 


\section{Magistrates Courts}

There are three classes of magistrate in Fiji. These are resident magistrate, second class magistrate and third class magistrate. Magistrates are assigned to divisions and this defines their jurisdiction in territorial terms.

In civil matters magistrates have jurisdiction to hear: (a) claims in contract or tort where the amount involved does not exceed $\mathrm{F} \$ 15,000$; (b) proceedings between landlord and tenant where the annual rental does not exceed F\$2,000; (c) all suits involving trespass or recovery of land (other than landlord and tenant disputes); applications for habeas corpus, and (d) application for guardianship or custody.

The criminal jurisdiction of magistrates is defined by clauses 4-9 of the First Schedule of the Criminal Procedure Code. The Code identifies which class of magistrate, as noted above, can hear a particular matter. Criminal sentences are also imposed by magistrates according to their class. Within the system of magistrates there are rights of appeal. A resident magistrate has jurisdiction to hear appeal from decisions of second and third class magistrates.

\section{The Executive}

Chapter 7 of the 1997 Constitution deals with executive government. Section 85 vests the executive authority of the State in the President who, by section 86, is constituted Head of State and the symbol of unity of the state. The President is also the Commander-in-Chief of the military forces (section 87). Provision is also made for a Vice President who deputises for the President on appropriate occasions (section 88). Either may be removed from office under section 93 on the grounds of an inability to perform the functions of office (whether arising from infirmity of body or mind or any other cause) or for misbehaviour. No other grounds for removal are possible. Section 93(3) provides for the establishment by the Chief Justice on the request of the Prime Minister of an investigative tribunal to hear allegations of misconduct by the President or Vice President.

The President is subjected to the principles of responsible Cabinet government with appropriate constitutional limitations on the President's power. Section 96(1) of the Constitution provides inter alia that the President exercises executive authority and his or her powers generally "only on the advice of the Cabinet or a Minister or of some other body or authority prescribed by this Constitution for a particular purpose as the body or authority on whose advice the President acts in that case." As noted above, the President is denied any legislative function which is the prerogative of the Parliament alone.

The Constitution however prescribes that certain powers can be exercised by the President without advice. This includes the power of appointing a Prime Minister, as 
noted above. The President also has the power of ascertaining under section 108 an alternative Prime Minister where an incumbent Prime Minister, who has lost the confidence of the House of Representatives, advises a dissolution of the House. Where there is an alternative Prime Minister who has the confidence of the House the President may ask the defeated Prime Minister to resign, dismiss him or her if he or she does not do so and appoint the alternative Prime Minister. If not, the President may grant the dissolution advised by the defeated Prime Minister. Another such situation is the President's power of appointment of a caretaker Prime Minister under section 109(2). By section 109(1) the President may only dismiss a Prime Minister where the Government fails to get, or loses the confidence of the House of Representatives and, concurrently, the Prime Minister does not resign or ask for a dissolution of the Parliament. In such a case the President may, acting on his or her own judgment, appoint another person as a caretaker Prime Minister to advise a dissolution of the Parliament.

Pursuant to section 104 of the Constitution the Prime Minister is obliged to keep the President generally informed about issues relating to the governance of Fiji. Furthermore he/she must supply the President with such information as the President requests concerning matters relating to the governance of the country. The President is invested with the prerogative of mercy under Part 5 of the Constitution. The President is assisted in this regard by a Commission provided for in section 115(2). In exercising the prerogative the President is bound to act on the advice of the Commission.

Part 4 of the Constitution provides for the appointment of government departments to carry on the business of executive government. Authority with respect to the working of such departments is vested in the respective Ministers. In general the notions here also comply with those of British responsible government.

\section{Great Council of Chiefs}

The Great Council Of Chiefs or Bose Levu Vakaturaga was created by the British colonial administration in the late nineteenth century and reconstituted in the twentieth century by the Fijian Affairs Act. Section 116(1) of the 1997 Constitution provides that the Council continues in existence and its membership, functions, operations and procedures are as prescribed from time to time by the Fijian Affairs Act. Subsection 116(2) provides that the Council has, in addition to the functions set out in the Fijian Affairs Act, the functions conferred on it under the Constitution. By section 64 of the Constitution the Council selects 14 of the 32 members of the Fiji Senate. Under section 90 of the Constitution the President and Vice-President are both appointed by the Council, although the Council is required in that regard to consult with the Prime Minister. 
The role of the Council in the political system of Fiji is a point of some contention. The Council was a colonial creation but the original members were not entirely representatives of chiefly groups at the time. Rather it was constituted by those favourable to the colonial administration. Notwithstanding this, the Council purports to anchor its authority in the customs and traditions of the indigenous Fijian peoples. After the May 2000 coup attempt there have been attempts to depict the Council as if it embodied a traditional customary authority which is much broader than the functions assigned under the written constitution. Certainly it tends to perceive itself not merely as the guardian of indigenous interests, but as having a higher political authority based on the paramountcy of the indigenous people. Thus it is often suggested that it has an authority which precedes the authority of the Constitution itself. On this basis, after the Fiji Court of Appeal decision in Prasad's case the Council appeared to maintain the right to determine, not so much how the decision ought to be implemented, but whether or not the rule of law and the decision of the Court should be followed at all. Clearly such a view conflicts with the idea that the Constitution itself is the supreme law. The Council, however, seemed to claim the prerogative to determine who a new Prime Minister should be, this being a power which the Council clearly does not have under either the Fijian Affairs Act or the 1997 Constitution.

\section{E Other Institutions}

The military force in Fiji Islands is called the Republic of Fiji Military Forces. ${ }^{20}$ As noted above, the Military played a key role after the May 2000 coup attempt, assuming authority pursuant to a State of Emergency and then through the Commodore's assumption of authority as Head of State under a Military Government. Section 112(1) of the Constitution provides for the continuation of the Forces established by the Constitution of 1990. The Military is headed by a Commander who is appointed by the President on the advice of the Prime Minister (section 112(2)).

A Human Rights Commission is established by section 42 of the Constitution. The Commission is chaired by the Ombudsman who sits with one member who is a judge and one other member. The three functions of the Commission are defined by section 42(2) as follows:

- to educate the public about the nature and content of the Bill of Rights which is established under Chapter 4 of the Cnstitution. This includes education as to its origins in international conventions and other international instruments, and the responsibilities of the Human Rights Committee, the Committee on the Elimination

20 The current name is an anachronism. 
of Racial Discrimination and other organs of the General Assembly of the United Nations for promoting respect for human rights;

- to make recommendations to the government about matters affecting compliance with human rights, including the making of a recommendation that a particular question about the legal effect of a provision of the Bill of Rights be referred to the Supreme Court for its opinion; and

- to perform such other functions as are conferred on it by a law made by the Parliament.

The 1997 Constitution provides for miscellaneous other institutions and offices of government for the Republic. The most notable of these are:

- Departmental Secretaries (section 100);

- Director of Public Prosecutions (section 114);

- Solicitor-General (section 113);

- Commissioner of Police (section 111);

- Constituency Boundaries Commission (s75);

- Electoral Commissions (section 78);

- Speaker and Deputy Speaker (section 80) and President and Vice-President of the Senate (section 81);

- Leader of the Opposition (section 82);

- A Parliamentary Emoluments Commission;

- Secretary-General to the Parliament and Staff;

- A Judicial Service Commission (section 131);

- A Constitutional Offices Commission (section 142);

- A Public Service Commission as previously established under the Constitution of 1990 (section 142);

- A Disciplined Services Commission, being the former Police Service Commission established under the Constitution of 1990 (section 142);

- An Auditor-General (section 166);

- An Ombudsman (section 157). 


\section{PREDOMINANT CONSTITUTIONAL ISSUES IN THE FIJI ISLANDS}

Many of the contemporary issues surrounding the constitutional situation in Fiji are long standing and largely unresolved although no doubt exacerbated by the attempted coup of May 2000 and its aftermath. The following features will be discussed in due course as the main features affecting the framework of law and government in Fiji. Many of these features are in fact closely related and/or overlap to a considerable degree. They are, in summary, as follows:

(1) The failure of constitutionalism.

(2) Ethnic and social divisions.

(3) Absence of a national legal culture

(4) The inappropriateness of the electoral system.

(5) Colonialism versus independence.

(6) Tradition and modernisation

(7) The Role of custom within the legal/political system

\section{A The Failure of Constitutionalism}

Constitutionalism refers to the political and legal doctrine pertaining to the makeup of constitution. Constitutional politics is much broader than that represented by the written document or represented by the contents of it. Constitutionalism refers to the fundamental doctrinal principles which relate to particular forms of constitution. Thus it is an ideology supporting particular conceptions of a constitution. Whilst it is true that constitutional lawyers' attention is often focused on issues surrounding the meaning of words and phrases in an established constitutional document, such a view of constitutionalism is much too narrow. Constitution in a broader sense means the whole political makeup of a country and the written document is merely an aspect of this.

Legal dispute has traditionally been interpretative dispute, which, though it can produce seemingly radical results from time to time, usually proceeds on certain fundamental assumptions about the settled backdrop or structure provided, in a country like Fiji, by the constitutional document itself. Legalism holds that in interpreting or understanding a constitution primacy should be given to the constitutional document because it contains certain fundamental legal principles. Indeed the constitution should be interpreted as if it were essentially a legal rather than a political document.

The reference to constitutionalism is a denial of this narrow perception. The legist (usually positivist) claim is that taking the constitution as supreme law is an essentially self-legitimating idea. But the grounds of this allegation cannot be established without 
danger of contradiction, as if the supreme law somehow legally justifies itself. Justification is better found outside the written constitution within a framework of understanding which holds that a constitution is essentially a political document which embodies an expectation of the existance of a certain form of consensus or perhaps some alternative ideology. In that way constitutionalism is closely tied to acceptance of the rule of law. To put it another way, the constitution is accepted as embodying certain fundamental and permanent values and beliefs which are capable of being transmitted from one generation to another. The constitution in a basic sense provides not only a source of law, but purports to represent some reasonably pervasive framework of identity. Without some widely accepted doctrine of constitutionalism, the written constitution itself counts for little. It is easily cast aside in the pursuit of power politics. It is in danger of being regarded as some remote and alien impost. The adoption of written constitutions, especially in the Western tradition, is attended with certain doctrinal assumptions, norms and beliefs which together could be called 'modern constitutionalism'. These features are assumed in the 1997 Constitution of Fiji Islands. But there are grounds to doubt whether the assumptions of constitutionalist doctrine apply sufficiently to the country. In other words the issue is whether there is a failure of modern constitutionalism when applied to Fiji Islands.

This failure of constitutionalism can be approached in other ways. Indeed it overlaps with many of the other issues discussed here. However, the crisis in Fiji which arose in 2000 and the debate concerning the legitimacy, particularly of the 1997 Constitution, clearly illustrates this failure of constitutionalism and absence of belief in some of its basic assumptions. Speight's supporters proclaimed that the 1997 Constitution was illegitimate. It was something that could simply be cast aside because it was alleged to conflict with or at least not to reflect the interests of indigenous Fijians as a whole. As indicated below, the appeal to homogenous indigenous interests was never much more than a destablilising rhetoric utilised by Speight and his followers. For one thing it pretended to be a rallying point for this group even though it was itself internally divided into a number of discordant factions. More to the point, it is clear from events following the attempted coup that there was indeed a stated ambivalence amongst many indigenous Fijians themselves, including many self-proclaimed leaders, the Army and the Chiefs, about the claims levied by Speight and his group. Whilst many of them were not prepared openly to support the extreme claims of Speight, particularly in their anti-Indian rhetoric, there was clearly a failure to take forthright action to condemn the actions of Speight as well as an apparent willingness to accommodate some of Speight's claimed concerns regarding the inadequacy of the 1997 Constitution. Inaction, failure to condemn and a willingness to cooperate are sometimes very revealing factors in a situation such as this.

At a deeper level it is clear that the hold of the doctrine of modern constitutionalism in Fiji has been at best tenuous. The idea that a constitution can readily be ignored or cast 
aside when the demands of power politics, traditional or otherwise, deems it convenient is clearly a factor in Fiji society. It is what some prefer to refer to as a "coup mentality" brought into being by the successful coups of 1987. This, if anything, indicates that the rule of law and the legalist ideology which it supposes to exist, does not in fact hold.

Modern constitutional doctrine, which emerged in Europe at the end of the medieval period, postulates and perhaps requires certain fundamental assumptions. These assumptions were largely set against what was perceived to be inherent in the so-called ancient constitutions of Europe. One could say that these ancient constitutions functioned on the basis of some notion of consent to government which was the product of, and acknowledged an underlying diversity of customs and cultures. Modern constitutionalism, on the other hand, supposes a high degree of uniformity within and between members of a society. Theoretically, by a range of different strategies (such as appealing to notions of universal logic or rationality or universal postulates of human nature) it imposes that unity at the expense of cultural diversity. Sometimes the existence of this social uniformity, especially in terms of adherence to a pervasive national identity, has been claimed to be a manifestation of a higher or more profound stage of human development or a higher stage of progress. For example, modern constitutionalist theory creates conditions of abstract citizenship defined in terms of fundamental rights for all, fundamental equality and unified state sovereignty. The constitution is, according to this doctrine, a kind of overarching unity which has been created out of a compact between those who are fundamentally the same and which proceeds to treat them as the same in fundamental respects - viz as citizens with the same rights. ${ }^{21}$ Furthermore, very often, when confronted with great cultural diversity, it is law which provides the appropriate sense of identity because, in its abstract and formal state, it is capable of applying across several different cultural domains within a particular society.

Elements of this kind are clearly provided for in the 1997 Constitution of Fiji as indeed in its predecessors. There is no doubt whatsoever that the 1997 Constitution is well written and clearly articulated. It conforms in most ways and in a high degree to the now conventional European model of written constitutions both in form and content. Not insignificantly, one of the features of modern constitutionalism is, not only that there should be internal uniformity or unity, but that the assumptions made by modern constitutions are universal in nature. Thus it is no accident that constitutions internationally should appear similar in many vital respects. Indeed it is no accident also

21 James Tully identifies seven features of modern constitutional doctrine which were then used as a kind of ploy to exclude ancient constitutionalist argument entirely, often by treating it as irrelevant, outmoded, traditional or illogical. See J Tully Strange Multiplicities: Constitutionalism in an Age of Diversity (Cambridge University Press, Cambridge, 1995) 63 onwards. 
that the Constitution of Fiji appears to embody ideas and principles which are also found in other Commonwealth and European constitutions, as well as many other Pacific island countries. Some would prefer to attribute this feature to post-colonial imperialism, whilst others might see it as the outcome of a process of modernisation. At the very least, it stands as evidence of the assumption, made by the framers of the Constitution, that Fiji is a country in which the doctrines of modern constitutionalism have some tenability or purchase.

Whilst it might be thought that the principles of a constitution are based on sound logic or rational principles which necessarily apply to societies composed of rational and reasonable people, the recent events in the Fiji Islands give ground to consider whether this universalist assumption holds. No doubt the majority of the people of the country are reasonable and rational but perhaps not in the way in which modernist legal theory and the colonising European countries have assumed. For the moment we need only ask whether the assumptions of modern constitutional doctrine are sufficiently grounded within the community or culture of Fiji.

One would have to say that this is an extremely doubtful proposition. For one thing, Fiji is neither as ideologically uniform nor as culturally homogeneous as the 1997 Constitution and modern constitutionalist doctrine assumes. It remains, in a variety of ways, significantly divided, to such an extent that these assumptions, however expressed, are frequently regarded as either meaningless or irrelevant. The cultural divide is not one between indigenous Fijians as opposed to Indians and miscellaneous others. The divisions exist within indigenous society itself which have largely prevented the formation of any pan-national identity. Fijian society remains divided in terms of the vanua or confederacies which were established some centuries ago as a result of warfare. Even these are further sub-divided in significant ways. Thus one can say that the model of modern constitutionalism is simply out of step with the underlying social and cultural diversity of Fiji. There is a clear gap between the facts of life in Fiji and the (mostly normative) theoretical assumptions of modern constitutional doctrine. This hiatus is between the artificiality or abstraction involved in the modern theory of constitutional sovereignty, on the one hand, and the cultural diversity that goes on underneath and regardless of it, on the other.

Against this, it could be argued that the 1997 Constitution does recognise diversity. It is in some clear respects a multi-cultural document. The 1997 Constitution of Fiji Islands expresses itself in Chapter 3 to be a compact between autonomous agents. It implements an approach which is favoured by liberal ideologies regarding the establishment of a state or a political society. The social contract in this case is the initiating ground for the creation of the political/legal order which the constitution proceeds to establish. Chapter 3 appears directly to assume the existence of such a contract when it provides for establishment by 
way of 'Compact'. The terms of this 'Compact', however, indicate features of multiculturalism. This is evident from section 6, although the rights to which it refers are not justiciable rights. ${ }^{22}$ This section is as follows:

6. The people of the Fiji Islands recognise that, within the framework of this Constitution and the other laws of the State, the conduct of government is based on the following principles:

(a) the rights of all individuals, communities and groups are fully respected;

(b) the ownership of Fijian land according to Fijian custom, the ownership of freehold land, and the rights of landlords and tenants under leases of agricultural land are preserved;

(c) all persons have the right to practise their religion freely and to retain their language, culture and traditions;

(d) the rights of the Fijian and Rotuman people include their right to governance through their separate administrative systems;

(e) as citizens, the members of all communities enjoy equal rights, including the right to make their permanent homes in the Fiji Islands;

(f) the rights of a citizen include the right to form and join political parties, to take part in political campaigns, and to vote and to be a candidate in free and fair elections of members of the House of Representatives held by secret ballot and ultimately on the basis of equal suffrage;

(g) the formation of a government that has the support of a majority in the House of Representatives depends on the electoral support received by the various political parties or pre-election coalitions, and, if it is necessary or desirable to form a coalition government from among competing parties, depends on their willingness to come together to form or support a government;

(h) in the formation of a government, and in that government's conduct of the affairs of the nation through the promotion of legislation or the implementation of administrative policies, full account is taken of the interests of all communities;

(i) to the extent that the interests of different communities are seen to conflict, all the interested parties negotiate in good faith in an endeavour to reach agreement;

(j) in those negotiations, the paramountcy of Fijian interests as a protective principle continues to apply, so as to ensure that the interests of the Fiji an community are not subordinated to the interests of other communities;

22 See the 1997 Constitution, art 7 
(k) affirmative action and social justice programs to secure effective equality of access to opportunities, amenities or services for the Fijian and Rotuman people, as well as for other communities, for women as well as men, and for all disadvantaged citizens or groups, are based on an allocation of resources broadly acceptable to all communities;

(1) the equitable sharing of political power amongst all communities in Fiji is matched by an equitable sharing of economic and commercial power to ensure that all communities fully benefit from the nation's economic progress.

Furthermore, the 1997 Constitution was the product of widespread consultation and discussion in Fiji before it was adopted. This was directly indicated in the Prasad case and is no doubt true. But, notwithstanding the provisions of section 6, there are two significant questions. The first is whether the Constitution is premised on assumptions that are untenable; that is, that the assumption of some underlying compact between autonomous and consenting individuals is at odds with the social and cultural realities in the country. The second is whether the 1997 Constitution, which pays some attention to multicultural principles, goes far enough.

On the second issue, the 1997 Constitution does recognise the principle of diversity in some important ways. Section 6 does so even though, as indicated, the rights are not justiciable. The Constitution also purports to do so in Chapter 13 on Group Rights in that it purports to entrench, to some degree, existing legislative schemes with respect to customary rights and the rights of Rotumans, Banabans and so on. ${ }^{23}$ The Court of Appeal claimed in Republic of Fiji $v$ Prasad that this scheme provided adequate protection of the rights of indigenes and therefore other cultural groups in the country as follows:

The 1997 Constitution was made in Fiji for Fiji by the Parliament and people of Fiji. It contains many of the rights and freedoms mandated by international instruments. It protects the rights of the indigenous people and entrenches some of those rights as we have detailed earlier. The extensive consultation undertaken by the Reeves Commission that preceded its adoption in Parliament provides strong evidence that the 1997 Constitution reflected the will of the great majority of the people of Fiji. It is permissible when assessing the test for efficacy in this context to take into account the evidence which suggests contentment with or acceptance of the 1997 Constitution by the population at large. Such acceptance militates against the proposition that there has been general acquiescence in its abrogation.

But the question is whether a scheme such as this goes far enough simply because it is a rights based regime which, at another level, simply ignores again the factor of substantive cultural diversity in the country. The idea that liberal constitutions should make

23 These provisions are discussed further below. 
accommodations to cultural diversity in this way is evidence of a latterly adjustment to liberal political doctrine. If once it was assumed that the liberal project was one world wide assimilation pursuant to fundamental human rights provisions and so on, it has been increasingly recognised that such a project of global homogenisation is clearly at odds with the rights of minorities and particularly of indigenous peoples. Thus recourse has been had to group rights. ${ }^{24}$

However that might be, the lingering problem is still that the Constitution purports to provide this recognition at a formal 'legal' level in terms of rights. Without a supporting national ideology or cultural identity which is the genuine product of an interaction of diverse cultures, this amounts to mere empty formalism. Like sovereignty theory, the various tenets of the doctrine of modern constitutionalism could well retain the character of external imposition rather than the product of an internal dynamic.

\section{B Ethnic and social divisions}

It is easy to (mis)conceive the contemporary politics of Fiji merely in terms of issues of Fijian versus Indo-Fijian ethnicity. Clearly enough the Constitutions of 1970 and 1990 indeed reinforced those divisions to a considerable extent. There is no doubt that the Speight-led coup attempt sought to exacerbate whatever tensions might have existed between those ethnic groupings by pleading the simplistic cause of protection of indigenous Fijian interests as the motive for the attempted coup. Some of the rhetoric was and is clearly fascist in its orientation, sometimes tending towards proclamation of the need for ethnic cleansing. But, as we have just noted, this racist rhetoric obscures the fact that indigenous Fijian culture is itself as divided as it was prior to cession. More recently there are divisions between the traditional cultures and the kind of parvenu commoner represented by Speight and, in a different way, by Rabuka. This in turns raises questions about the cogency of a pervasive identity even in respect of indigenous Fijians themselves.

Sometimes this manifests in terms of complaints levelled, for example, against the Native Lands Trust Board (see below) of not protecting the interests of custom owners and of nepotism. It was also brought out after Speight's attempted coup when the Western confederacy sought to secede from Fiji and establish its own state, possibly in free association with the United States of America. Similar, but less serious, calls were also made by the Northern confederacy at one stage. This at least revealed a deeper dimension to the crisis than that of Fijian versus Indian. The prospect of Fijian against Fijian is treated by many of the indigenous peoples as anathema, but this is precisely what came to pass on

24 Kymlicka argues the liberal need for accommodation of group rights here very well. But the liberal assumption of uniformity which must ultimately be at odds with cultural diversity remains. See W Kymlicka Multicultural Citizenship (Oxford University Press, Oxford, 1995). 
2 November 2000 when members of the Counter-revolutionary Warfare Unit staged an armed revolt at the Army barracks in Nabua in an attempt to oust Army leadership loyal to the existing regime.

The 1997 Constitution of Fiji and those before it pays little attention to tension and conflicts between indigenous cultural and regional groups themselves. The Constitution, nonetheless, is an egalitatarian and democratic document which purports to take effect as a compact between consenting peoples. Both its legitimating rhetoric and its model is that of liberal democracy. It speaks much of unity and cohesion and clearly assumes the achievement of these as its fundamental premise. It purports to guarantee fundamental rights and freedoms and the promotion of social and individual equality. But the question is whether this is a mere theoretical expectation without grounding in cultural reality.

\section{Absence of a Strong Legal Culture}

Legal culture is a flexible and, perhaps, amorphous concept. Culture, in an ideational sense, usually indicates a set of shared ideas, values, beliefs and principles which provide a sense of commonality within a particular social group. Further it indicates ideas, values and so on which are transmitted from one generation to another, providing the groups with some sense of continuity through time. The link between culture and group identity is therefore a very strong one. It is the notion of shared ideas, values and so on, which are intrinsic to culture, which in effect provide the substance to and define identity.

Legal culture is obviously a more specific notion. It is not used merely to capture the shared ideas, values, beliefs and principles which are common to the legal profession, and a range of legal actors such as judges, magistrates, government legal officers and police. The legality principle of a legal culture is not self-defining. Regardless of what reflexive theories of law tell us, legal culture builds on the interaction with society outside in a range of complex ways. In other words, legal culture has a two-sided or dialectical character. It includes ideas and so on which are common to legal actor groups, but it also purports to capture the sense in which these ideas stand in relationship to and are affected by those who stand outside the group or, in this case, the profession. Ideas both inside and outside stand in kind of nurturing relationship to one another.

In Fiji it is clear that legal culture is weak. This is not to say that the legal profession, the judiciary or other legal actor groups are themselves weak or lacking in commitment, determination or purpose. That is perhaps a matter of inference from the failure of the police and the military to quickly resolve the hostage crisis in May 2000. So far as legal culture is dependent upon and supported by ideas, beliefs and values from the non-legal community, it is clear that the culture is in some degree of crisis. It would only be a strong legal culture which could lay open the possibility that law or the legal system might itself 
provide the necessary sense of identity which the 1997 Constitution presupposes in the face of cultural diversity. ${ }^{25}$

Legal culture in Fiji purports to be closely imitative of that of the British common law system. But as we noted earlier there has been little attempt on the part of local courts or legal actors to achieve anything like an integration of custom and law. The courts have long sequestered custom, refusing to treat customary issues as justificiable issues. The justification for this has usually been that should the courts interfere in customary matter by finding similarities to common law principles and ideas then this would amount to a distortion of custom. Furthermore it could be taken as an interference by the courts with the authority of the custom system. But this kind of Mexican stand off itself encourages and endangers the long term viability of custom. The fear is that, with urbanisation and westernisation, introduced law with simply obliterate custom altogether. Ignoring it hardly protects custom. Nor does shunning custom develop the possibility of a jurisprudence which is distinctive to the country, one in which there is some possibility of forging a legal identity which might unite the country to some greater extent than has been shown to date.

\section{The Inadequacy or Inappropriateness of the Electoral System}

The 1990 Constitution of Fiji purported to entrench the predominance of indigenous Fijians in two ways. The first was the electoral system. The second was a guarantee of the rights of indigenous Fijians particularly as regards land and other customary interests. As regards the former, section 41 of the 1990 Constitution provided for the establishment of a lower house of parliament, The Legislative Assembly, consisting of seventy members but with an entrenched majority of indigenous Fijians. According to section 41(2) of that Constitution voters were streamlined into different electoral roles according to predominant races; namely Fijians, Indians, Rotumans and finally those who were neither of the above. The last group lumped together a reasonably significant Asian and European citizen population in Fiji. Of elected members, it was provided by section 41(3) that 37 members had to be elected from the roll of indigenous Fijians, 28 from the Indian roll, one from the Rotuman roll and five from the remaining roll.

The distribution of seats for the House of Representatives under the 1997 Constitution purported to achieve a fairer representation of the various communities in the Fiji Islands when compared to the 1990 Constitution. The 1997 Constitution provides for 71 members to be elected to the House of Representatives. The representation of the House of

25 This claim of legal identity in the face of great cultural and individual diversity is frequently made in the United States of America as if it were somehow distinctive to that country. There is in fact nothing distinctive about it. 
Representatives is of two kinds; 46 members of the House are elected on communal lines and 25 members are elected by voters from all the communities (open seats). The 46 communal members of the House of Representatives comprise 23 for Fijians, 19 for Indians, one for Rotumans and three for General voters (those other than Fijians, Indians or Rotumans).

Among the new features of the 1997 Constitution was the provision for a multi-party Cabinet. This provision required that the Prime Minister must offer seats in the Cabinet to members from all parties which secure at least 10 per cent of the 71 seats in the House of Representatives. In choosing members of the Cabinet, the Prime Minister must make sure that they represent a fair proportion of their party's total membership in the House of Representatives.

If members of those parties invited to be represented in the Cabinet decline that invitation, the Prime Minister may invite members from his or her own party or coalition of parties to fill the remaining seats. The multi-party Cabinet concept is for the benefit of all groups in the community as it aims to achieve consensus decision-making among the leaders of the different ethnic groups. It also ensures that interests of all sectors of society are taken into account when important policy decisions and laws are made.

After the Speight coup there were many indigenous groups that complained that the Chaudhry-Labour coalition was ushered into power as a result of the new electoral system. Some also attributed the failure of Mr Rabuka's faction in particular to be due to the perception that Rabuka has 'sold out' on traditional Fijian interests by endorsing a constitution which was "too liberal". But the electoral result would have been no different regarding the balance of power if the electoral system had been a first past the post system rather than the associational system under the 1997 Constitution. Rabuka's failure was most likely attributable to the record of his pre-election government than otherwise. If there was a cause of the failure of the established Fijian politicians in the election it was due, again, to the divisions between the Fijian parties.

\section{E Colonialism and Independence}

Fiji was ceded to the British in 1874 by the paramount chief George Cakobau. The legal system including most of the main institutions of Fiji such as the courts, the parliament and the public service were created in the image of the legal system of the coloniser. Since independence Fiji has been a republic headed by a President, but the constitutional structure has relied heavily on the principles of responsible Cabinet government or Westminster-style government derived originally from Britain. Indeed, these principles were firmly enshrined in the 1997 Constitution of Fiji with some more effort than is usual to define the relationship between the President and the Cabinet and Parliament. 
Development of legal principle through the courts in Fiji , even since independence, has closely followed the lead of English law rather than the law of either other South Pacific countries or the larger neighbouring countries of New Zealand and Australia. However there have been some signs of change more recently with the courts paying more regard to authorities from more proximate jurisdictions. This has been partly due to the utilisation of members of the judiciary from these other jurisdictions particularly at the level of the High Court and the appellate courts. However, despite the fact that Fiji has very much been at the centre of the international politics of the South Pacific region, neither its courts nor its legal reform agencies have done much, if anything, to contribute to the development of distinctive jurisprudential principles relating to the region. In fact, in the case of Fiji, the courts have tended to insulate one of the key possibilities for development of such a jurisprudence; namely custom. Custom in Fiji relates especially to land. Aside from that, the High Court of Fiji has adopted the stance that custom and introduced law are mutually exclusive realms. This, in itself, has prevented the development of a legal system that is properly responsive to and in line with cultural diversity.

There are many aspects of the legal system in Fiji which are the historical products of the colonial experience. Even institutions such as the police and the legal profession are influenced by this heritage. It has been pointed out elsewhere that colonialism itself most often creates the concept of custom and customary law as something which is distinct from introduced European or state centred law. ${ }^{26}$ At the same time, it has tended to devalue the former at the expense of the latter. This has lead some writers to suggest that custom will eventually yield to introduced law, although clearly that has not occurred in Fiji at the present time.

It is true that in Fiji some of the key institutions of government and administration relating to indigenous customary ownership were created by the British colonial administration. The system of local village chiefs called turaga ni koro were so created. The Great Council of Chiefs was also such a creation. ${ }^{27}$ Yet it is odd that some political players in contemporary politics in Fiji, for example Rabuka, have spoken of the Great Council of

26 This feature has long been recognised by legal pluralists, who also acknowledge the fact that the debate about the existence of multiple centres of power also reflect debates aboiut the self determination of formerly colonised peoples.

27 See S Sharma "The Control and Protection of Native Lands in Fiji" (1999) 6 JSPL <http://www.vanuatu.usp.ac.fj/journal_splaw/Working_Papers/Sharma1.html>. Sharma comments (at 1): "Sir Arthur Gordon the former Governor General of Fiji took up the idea of setting up of the NLTB in the 1930's. One of his aims were to preserve the Native Land for the Fijians. The Great Council of Chiefs, however, wanted individual ownership. The main reason behind communal ownership was to prevent the landowner from being misled into selling their land at a low price. Accordingly, his idea was to have a body in the form of a trustee to look after the interests of the Fijian landowners who would be the beneficiaries." 
Chiefs in terms which would suggest that it maintains a traditional authority which transcends the authority of any given constitution. Rather than being seen as a colonial institution serving British colonial interests, it has been elevated to a status of an institution which maintains some eternal (and allegedly pre-colonial) authority.

The Native Lands Trust Board and the system of communal ownership which it sets up was also a creation of the British administration. It plays a key role in the administrative of customary land on behalf of indigenous groupings pursuant to the Native Lands Act. ${ }^{28}$ In fact the regulation of customary or native land in Fiji is regulated by three pieces of legislation. These are the Native Lands $\mathrm{Act}^{29}$ the Native Land Trust $\mathrm{Act}^{30}$ and the Agricultural Landlord and Tenants Act. ${ }^{31}$ Of these, the Native Lands Act serves largely to preserve the interests of the Fijians in native lands. For example, section 3 of the Act provides that native lands shall be held by native Fijians according to native customs as evidenced by usage and tradition. The interests of the illegitimate Fijian children are preserved by deeming them to be owners of native lands and entitling them to be recorded as members of either their fathers or mothers landowning groups.

Section 4 of the Act establishes a Native Land Commission to determine disputes as to rights in Fijian land and to record the boundaries to such land including easements or encumbrances. The Commission also has powers to resolve land disputes. Under section 7 of the Native Land Trust Act, the decision of the Commission can be appealed within 90 days of its decision to an Appeals Tribunal. The Commission has power to resolve disputes concerning the rights of each landowning group in respect of customary land. It can also record boundaries to such a land and settle disputes about the head of a matagali (which is the basic land owning unit in Fiji) or other customary land owning group. Under sections 4 and 5 of the Act, the Minister of Fijian Affairs appoints one or more commissioners to the Commission. Provision is also made for provincial membership in terms of elected assessors and ex officio members from the relevant province in which the dispute or issue occurs. However it should be noted that disputes relating to customary land do not occur with great frequency in Fiji. Hence this mechanism for dispute resolution is not widely used. As noted above, the court system in Fiji denies itself jurisdiction with respect to disputes of this order.

28 Native Lands Act (Fiji) Cap 133.

29 Native Lands Act (Fiji) Cap 133.

30 Native Lands Trust Act (Fiji) Cap 134.

31 Agricultural Landlord and Tenants Act (Fiji) Cap 270. 
Section 3 of the Native Land Trust Act ${ }^{32}$ established the Native Land Trust Board (NLTB) which acts as a trustee for the landowners. This Board consists of the President of Fiji (formerly Governor-General) as the President, the Minister of Fijian Affairs as the Chairman, five Fijian members appointed by the Great Council of Chiefs and three Fijian members appointed by the Fijian Affairs Board. The NLTB is managed by the indigenous Fijians whilst technically vesting ownership inalienably in indigenous Fijians. Accordingly: ${ }^{33}$

The Act guarantees under section 5 that native land may not be alienated except to the Crown.

This is justly strengthened by article 38(8) Constitution (Amendment) Act 1997 which also protects against the alienation of land and fishing rights under custom. Section 4 vests the control of all native land in the NLTB and all such land shall be administered for the benefit of the Fijian owners.

In recent times there has been an increasing number of expressions of public dissatisfaction with the way in which the Board has performed its functions. Whilst the Board is charged, for example, with the collection of income from the rental of customary lands on behalf of customary owners, and the utilisation of that income for the advancement of indigenous interests, there have been claims to the effect that the allocation of such income has been governed by nepotism rather than the general objectives of the legislation. ${ }^{34}$ This, in turn, has seen a number of owners of customary land raising concerns about the loss of control of their customary lands to the Board. But the recourse of traditional customary owners against the Board is limited. One reason is that customary owners cannot be held to have individual justiciable rights with respect to mataquali lands. This was decided by the Supreme Court of Fiji in Meli Kaliavy $v$ Native Lands Trust Board. ${ }^{35}$

The Agricultural Landlord and Tenant Act (ALTA) came into being in 1966. Its major objective was to establish some reasonably sound basis for the occupation of agricultural land by Fijians and non-Fijians. It also purported to create standard terms and conditions relating to tenancy contracts. This was of some considerable importance in respect of the occupation of sugar cane growing land by the Indo- Fijian community. The importance of the legislation can readily be appreciated considering the importance of the sugar industry to Fiji, an industry which depends extensively on tenanted land for sugar cane cultivation.

32 Native Land Trust Act (Fiji) Cap 134.

33 See Sharma, above $\mathrm{n} 27$.

34 Sharma, above $\mathrm{n} 27$.

35 Meli Kaliavy $v$ Native Lands Trust Board 5 FLR 17 (SC Fiji). 
The legislation purported to provide protection for agricultural tenants in respect of eviction and improvements similar to agricultural holdings legislation in other jurisdictions. The Act made provision for certain presumed tenancies and imposed limitations on ejectment in certain circumstances. For example, by section 4 , where a owner (including the NLTB) had taken no steps to evict a user of agricultural holding who had been in possession and cultivating the holding as a tenant for at least three years an owner seeking to evict was under an onus to prove that the occupation was without consent. Disputes which arise with respect to interests created under the Agricultural Landlord and Tenants Act are of a different order than those with respect to customary land per se. Pursuant to section 42 of the Act, these are to be dealt with initially by the Agricultural Tribunal. Pursuant to section 48 an appeal lies from there to the Central Agricultural Tribunal. No further appeal is provided in the legislation, however, it is possible to seek judicial review of the decision on natural justice grounds by the High Court of Fiji. ${ }^{36}$

The legislative scheme under ALTA was the focus of public concern and debate during the year of Chaudhry government. One issue, from the point of view of some indigenous Fijian groups, was that of return of existing ALTA land to them (not always seen favourably particularly in the Western region) whilst from the point of view of the Indian farming community the issue was one of security of tenure. The payment of compensation pursuant to section 40 of the Act was contingent upon improvements having been made by the tenant with consent of the landlord. Furthermore, the Act created no right in the tenant to remain in occupancy pending the payment of compensation. ${ }^{37}$ Rational debate on the issue of rational tenancy reform was severely hampered by the misrepresentation of the intentions of the Labour coalition government, especially in protecting the rights of indigenous Fijian rights to customary lands.

\section{F Tradition versus Modernisation}

Arguments about tradition and modernity are very often arguments about legitimacy and political authority. In this light, arguments about the traditional, village-based or communal nature of indigenous Fijian society often appear as arguments designed to legitimate the claims to government of those who properly represent or, at least respect, those interests. Similarly, arguments as the status of custom and customary law are linked to issues of self-determination and independence from former colonial rule.

In one sense, it is clear enough that Fiji is a mixture of traditional and modern societies. In the latter respect the development of an urban culture has been significant over the last twenty years as evidenced by the urban drift towards Suva and Nadi along with the

36 Sharma, above n 27.

37 See Hari Prasad Mintar v NL TB (January 1999) Unreported High Court of Fiji. 
growth of new industries and commercial enterprises apart from the two major areas of tourism and sugar farming. Although significant, the forces of modernisation have not been strong; that is, if we take modernisation, not merely as a process of economic development, but as the development of a culture according to Weberian notions of modernity. Even in Suva where there is something like an educated and professional middle class amongst members of the indigenous Fijian population, the majority appear to retain strong identifications with their traditional cultures.

So far as issues of legitimacy go, there is clearly considerable confusion between lines of traditional and modern authority structures. Traditional authority structures remain significant amongst the Fijian population but not entirely so. It is certainly not so to the extent to which some Fijian governments as well as Speight have attempted to make out. Immediately after the coup in 1987 the Rabuka led government adopted a strong traditionalist line of argument extolling the virtues of village life and traditional authority and culture. This stance remained however only for a short time. In the early 1990s the Rabuka government appeared to shift in the direction of a programme of rapid and deliberate economic and cultural modernisation, purporting to make extensive borrowings on the experience of government in Malaysia.

It was this programme of modernisation which produced the 'overnight millionaire' group within Fiji (both Indian and Fijian) which Speight appeared to many to represent in the 2000 coup attempt. It is that group which appeared most disaffected by the 'anitcorruption' policies and measures of the Chaudhry government. In turn it was those disaffections which lead to the engineering of the coup attempt. Thus one could say that it was an attempt at rapid modernisation of the country by the Rabuka government itself which lead to the failed coup attempt. The invocation by Speight of traditionalist principles in support of his action was just another example of how modernisation creates and strategically employs its own concept of tradition - fabricating it as a powerful legitimating ideology but also disregarding it when the need arises.

\section{G The Role of Custom within the Legal/Political System}

As noted above, the role of custom in Fiji is confined to land and land ownership. It was also noted that fundamental aspects of the system of customary ownership and dealing with customary land was created by the British colonial administration in the 1930s. But that system has been retained after independence. It was also noted that the court system in Fiji perpetuates the distinction between introduced law and custom by denying the justiciability before the courts of issues of custom.

It is arguable, although certainly not established, that the status of custom within the legal system of Fiji was subtly changed by the 1997 Constitution. It is notable at least that this was not raised openly as an issue during the May 2000 coup or in the immediate 
aftermath. Section 100(3) of the 1990 Constitution recognised the Fijian custom as part of the laws of the country. In effect, as with the Solomon Islands legal system, custom was there clearly given the status of an independent body of law rather than being treated just as a source of law. However, under the 1997 Constitution of Fiji section 186 provides, on one (perhaps too immediate) view, merely that Parliament must make provision for the application of indigenous custom. The section states:

86.- (1) The Parliament must make provision for the application of customary laws and for dispute resolution in accordance with traditional Fijian processes.

(2) In doing so, the Parliament must have regard to the customs, traditions, usages, values and aspirations of the Fijian and Rotuman people.

(3) The Parliament must make provision granting to the owners of land or of registered customary fishing rights an equitable share of royalties or other moneys paid to the State in respect of the grant by the State of rights to extract minerals from the land or the seabed.

Section 186(1) might appear, then, to have challenged the independence of customary law as a body of law and to have relegated it, at best, to a possible source of law and even then, only if Parliament should have so provided. Even though Parliament is compelled to provide for customary law and dispute resolution in some way, it renders (on one view at least) custom as subordinate to legislation. It is to be noted, however, that the provision refers only to the "application" of customary laws and dispute resolution. If the issue is one of status, the word "application" would tend in the other direction; namely, to the effect that Parliament is merely charged under this provision with implementation of that which exists independently. It is curious nonetheless that the application is to be "in accordance with traditional Fijian processes", but, under section 186(2), in light of the traditions of both Fijians and Rotumans.

The 1997 Constitution also provides, by virtue of section 195 (2) (e), as follows:

195 - (2)(e) [Despite the repeal of the 1990 Constitution]... all written laws in force in the State (other than the laws referred to in subsection (1)) continue in force as if enacted or made under or pursuant to this Constitution and all other law in the State continues in operation;

On the basis that customary law under the 1990 Constitution was given the status of a separate body of law, one could be drawn to the conclusion that it is preserved as law under this section. This assumes that the words "all other law in the State" are not to be read down by the preceding references to "all written laws". But there appears no real reason why they should be.

To some considerable extent the regime relating to customary lands existing prior to the 1997 Constitution was preserved by section 185. With respect to the Native Lands legislation, a special procedure must be followed in order to amend the legislation which 
would, in fact, make it very difficult for any amendment to be achieved. This occurs in the context of Chapter 13 of the Constitution which purports to protect group rights. Section 185(1) applies to legislation such as Fijian Affairs Act, Fijian Development Fund Act; Native Lands Act, Native Land Trust Act, Rotuma Act, Rotuman Lands Act, Banaban Lands Act and the Banaban Settlement Act. The section required that the amendment proposal : (a) must be expressed as a Bill for an Act to alter the Act concerned; (b) must not be presented for the President's assent unless it has been read three times in each House and motions for the second and third readings are carried in each House; and (c) is deemed not to have been passed by the Senate unless at its third reading in that House it is supported by the votes of at least nine of the 14 members of the Senate appointed under paragraph 64(1)(a). Similar restrictions were imposed by article 185(2) with respect to the Agricultural Lands Tenancy Act although there a two-thirds majority of each house of parliament was required.

\section{PROGNOSIS}

Clearly the constitutional affairs of Fiji are in a state of disarray. The Speight coup is not so important for what it sought to achieve or what it purported, misleadingly, to represent. What is rather more telling is the aftermath of confusion and disarray in the country with respect to areas such as the status of the Constitution, the failure of particular legal offices to understand or perform the roles assigned to them and the comparable weakness of legal culture and the rule of law in the country.

The 1997 Constitution has been reinstated, but it remains on shaky foundations especially when it legitimacy seems to be subject to extra constitutional challenge on the part of the Great Council of Chiefs and other powerful actors within the complex politics within the countries. There is nothing wrong with the constitution according to the doctrinal assumptions which attend it. It is a very well written and comprehensive document which in terms of detail far exceeds the provisions of many of its counterparts in more developed countries.

Like many other Pacific countries Fiji is small but extremely diverse in the cultures it contains. What is urgent within the country is not so much the review of the written constitution to accommodate indigenous interests. What is more urgent is the establishment of an intercultural dialogue which holds some prospect of establishing a sense of national identity which will in turn sustain the platform of central government. But the forces of fragmentation are strong within Fiji, so strong perhaps that the idea of concessions to stronger regional government need also seriously to be considered.

There are other pressing needs. The imposition of sanctions against Fiji by traditional aid providers, allies and trading partners Australia, the European Union, the United States and New Zealand as a result of what was perceived as the failure of democracy (albeit 
liberal democracy) in Fiji will be a major contributor to further economic decline of the country. Already the destablisation of the country after May 2000 has severely damaged the tourist, sugar and garment industries upon which Fiji so heavily depends. Economic decline of this scale must inevitably lead to a more pervasive social destablilisation and problems with societal disorder and crime. The indigenous Fijians who desire it might well achieve some greater formal constitutional guarantees of priority of their own interests, but the fear is that this will be a Phyrric isolationist victory if expected economic decline materialises, as it seemingly must do.

\section{A POSTSCRIPT}

In September 2001 general elections were held in Fiji. The result was a victory for the Soqosoqo ni Duvavatana ni Lewenivanua (the Party of National Unity), the party of the former caretaker government members led by new Prime Minister Qarase. The Government was formed by way of a coalition with various minor parties. This included the Conservative Alliance Party, the party of attempted coup leader George Speight who, despite being elected as a member of Parliament in this election, remains in prison pending trial on treason and other charges.

The Fiji Labour Party, the party of ousted Prime Minister Mahendra Chaudhry, formed the main bulk of the opposition. Despite attracting the second largest vote, the Fiji Labour Party was excluded from participation in the multi-party Cabinet formed by Qarase under section 99(3) of the Constitution. Whilst section 99(5) of the Constitution requires the Prime Minister to invite the Fiji Labour party to participate, the Constitution is not clear on whether there is any obligation to appoint should the invitation be accepted. Section 99(5) provides:

99(5) In establishing the Cabinet, the Prime Minister must invite all parties whose membership in the House of Representatives comprises at least 10 per cent of the total membership of the House to be represented in the Cabinet in proportion to their numbers in the House.

This issue is the subject of further litigation initiated by the Fiji Labour Party in the Fiji High Court, concerned with interpretation of the section 99(5) and Part three of the Constitution. 